

Available online at http://www.anpad.org.br/bar

BAR, Rio de Janeiro, v. 12, n. 2, art. 4, pp. 190-208, Apr./June 2015

http://dx.doi.org/10.1590/1807-7692bar2015150025

$(\mathrm{co})$ EY-No

\title{
Brazilian Multinationals' Ownership Mode: The Influence of Institutional Factors and Firm Characteristics
}

Henrique de Azevedo Ávila Banco Nacional de Desenvolvimento Econômico e Social - BNDES

Angela da Rocha Pontifícia Universidade Católica do Rio de Janeiro - PUC-Rio/IAG

Jorge Ferreira da Silva Pontifícia Universidade Católica do Rio de Janeiro - PUC-Rio/IAG

Received 6 May 2015; received in revised form 14 May 2015; accepted 14 May 2015; published online 12 June 2015. 


\begin{abstract}
This work investigates whether host countries institutional factors and firm characteristics can help the understanding of Brazilian multinationals' choices of ownership mode for their foreign direct investments (FDI). Brazil is a privileged locus for research on emerging market multinationals (EMNEs), given its growing stock of outward FDI. The paper contributes to a better understanding of the international strategic choices of EMNEs. First, the phenomenon under study is examined using the theoretical lenses of institutionalism. Second, the study looks at the relationship between state support and choice of ownership mode, a new issue in the area of international business. Third, differences between the decisions taken by manufacturing and service EMNEs are also examined. Fourth, the study focuses on an emerging country, Brazil. The quality of the regulatory environment of the host country, and differences in beliefs, cultural identity and management practices between the host country and the country of origin are factors of the institutional environment significantly related to the choice of ownership mode by Brazilian EMNEs. As to firm characteristics, our results show that state support favors the choice of joint ventures, and that service EMNEs also significantly prefer joint ventures, when compared to manufacturing firms. The findings also support the view that EMNEs are less sensitive to institutional weaknesses in host countries.
\end{abstract}

Key words: institutionalism; ownership mode; institutional distance; regulatory environment. 


\section{Introduction}

The appearance of emerging multinational enterprises (EMNEs) has aroused great interest among academics, leading to the development of theoretical work and empirical studies aimed at verifying whether there are differences in motivations, pathways, processes and performance of these companies, compared to traditional multinationals from developed countries (Ramamurti, 2012; Sauvant, 2008). In spite of this, there are still important questions concerning whether differences are theoretically relevant, and, if so, whether they are adequately captured by the frameworks developed for multinationals from developed countries (Hennart, 2012). Therefore, new studies may help to revise or extend theories and models, by incorporating specific aspects of EMNEs (Cuervo-Cazurra, 2012).

This study adopts the institutional approach to analyze the choice of ownership mode by EMNEs. Dunning and Lundan (2008) suggested that the institutional approach offers a promising path to move forward our understanding of the different forms of contemporary multinational firms. Most theories that seek to explain the determinants of FDI emphasize economic variables. The research on entry modes is often based on transaction cost theory (Brouthers, 2013; Hennart, 1982; Rugman, 1981), which focuses primarily on the firm-specific and industry factors; institutional aspects are often treated as control or moderating variables (Agarwal, 1994; Barkema \& Vermeulen, 1998; Dikova \& Witteloostuijn, 2007). Nevertheless, since the beginning of the past decade, empirical studies have been conducted to assess the impact of host country institutional factors on FDI decisions.

This work investigates whether host countries' institutional factors and firm characteristics can help the understanding of Brazilian EMNEs' choices of ownership mode for their foreign direct investments (FDI). The following research question thus inspired the study: Is the choice of ownership mode by EMNEs related to certain host-country institutional factors and firm characteristics?

The paper contributes to the understanding of the phenomenon in several ways. First, the choice of ownership modes by EMNEs is examined using the theoretical lenses of institutionalism. Second, the study looks at the relationship between state support and choice of ownership mode, a new issue in the area of international business. Third, differences between the ownership-mode decisions taken by manufacturing and service EMNEs are also examined. Fourth, the study focuses on an emerging country. Brazil is a privileged locus for research on EMNEs, given its growing stock of FDI (although the annual flow of investments is still quite erratic). According to United Nations Conference on Trade and Development (UNCTAD, 2014), the country's stock of FDI abroad reached the figure of US $\$ 293.3$ billion at the end of 2013.

\section{Hypotheses Development}

\section{Institutional distance}

The term institution includes a heterogeneous set of factors, such as customs and beliefs, religion, judicial system, governance structures, and market mechanisms. Scott (2001) identifies three pillars in the institutional environment - regulative, normative and cognitive - which affect firm activities. Peng (2009) associated the regulatory pillar with the coercive power of government, expressed by formal institutions such as laws, regulations and rules; and the cognitive and normative pillars with informal institutions, such as culture and ethics.

The understanding that not only physical distance, but especially the perception of differences between countries of origin and destination influence internationalization decisions has already been discussed for several decades in international business literature. The construct of cultural distance, 
based on Hofstede's (1980) studies and operationalized by Kogut and Singh (1988), has been recurrently used to understand several aspects of firm internationalization, such as location (e.g. Grosse \& Trevino, 2005) and entry mode (e.g. Chen \& Hu, 2002; Hennart \& Larimo, 1998). In addition, the concept of psychic distance, applied by researchers at Uppsala School to the firm internationalization process (Johanson \& Vahlne, 1977), has also been extensively used in IB research. However, these constructs and their operationalizations have been criticized in relation to their conceptual weaknesses and measurement flaws (e.g. Shenkar, 2001).

The construct of institutional distance, developed and refined by Kostova and associates (Kostova, 1999; Kostova \& Roth, 2002; Kostova \& Zaheer, 1999), is believed to have greater explanatory power than the constructs of psychic distance or cultural distance, comprising not only sociocultural variables, but also institutional variables that may significantly influence business decisions (López-Duarte \& Vidal-Suárez, 2013; Tung \& Verbeke, 2010). Because the construct incorporates aspects of regulative, normative and cognitive distance, it is considered more suitable to explain the strategies adopted by multinationals. When multinationals face institutional environments very different from their country of origin, it is more difficult to establish and maintain their legitimacy (Kostova \& Zaheer, 1999), as well as to transfer headquarters' practices to the subsidiary (Kostova 1999; Kostova \& Roth, 2002). Host country institutional environment can impact multinational firms' decisions in two ways. In absolute terms, the level of institutional quality reflects the effectiveness, transparency and stability of institutions in the country, resulting in greater or lesser uncertainty; in relative terms, the differences between the levels of institutional quality of the country of origin and country of destination mean potential difficulties to gaining legitimacy in the new environment (Chan, Isobe, \& Makino, 2008; Phillips, Tracey, \& Karra, 2009).

Several authors have identified the influence institutional factors have on the choice of ownership mode, though not using the institutional perspective. For example, Goodnow and Hansz (1972) found empirical evidence that firms tend to adopt higher-control ownership modes in countries with favorable environments. In turn, studies based on transaction cost theory provide varying interpretations of the impact of cultural distance on the degree of control of the subsidiary (e.g. Anderson \& Gatignon, 1986). Even so, transaction cost theorists often see institutional factors as associated with the choice of ownership mode.

Although empirical studies have consistently shown that the higher the uncertainty associated with the institutional environment, the greater the preference for joint ventures, there is some discussion as to how the three pillars of institutional distance - regulative, normative and cognitive may impact FDI decisions. For example, when studying subsidiaries of Japanese multinationals, $\mathrm{Xu}$, Pan and Beamish (2004) found a negative association of regulative and normative distances with levels of participation in subsidiary capital. The authors did not test cognitive distance because they consider it a separate construct, which impacts multinationals' strategies through different mechanisms. This position is shared by Estrin, Baghdasaryan, and Meyer (2009).

Eden and Miller (2004) show that the establishment of joint ventures is advisable in host countries with large normative distance from the country of origin. However, the impact of cognitive distance on the choice of ownership mode is more complex, since different aspects of local firms' and consumers' behaviors can interfere in the decision. Trevino, Thomas and Cullen (2008) contend that the non-inclusion of normative and cognitive factors leaves the understanding of the impact institutions have on FDI decisions incomplete. There are also empirical studies in the literature whose results support the hypothesis of a negative association between the uncertainty of the institutional environment and the choice of joint ventures (e.g. Arslan \& Larimo, 2010).

Thus, in general the literature assumes that the greater the differences between the regulatory environments of the country of origin and of the host country, the greater the uncertainty and, therefore, the greater the probability of choosing a joint venture. However, this hypothesis carries a bias, probably due to the fact that most studies examined multinationals from developed countries, which enjoy high quality domestic regulatory environments and, as a result, are expected to find it more difficult to operate in low-quality regulatory environments. However, when considering the case 
of EMNEs typically coming from countries with poor regulatory environments, one should not assume that these companies prefer low-quality regulatory environments in the host countries simply because they are used to them in their countries of origin. In fact, what matters is the uncertainty generated by a regulatory environment of poor quality, regardless of the country of origin of the firm. Although it is possible that a company from a poor regulatory environment is better able to deal with the uncertainty arising from a similar environment in another country, it does not mean that the company prefers, or that it is easy for the company to operate in such environment. Thus, in the case of EMNEs, the impact of the regulatory environment in the ownership mode decision should not be evaluated by the difference (or distance) between the country of origin and country of destination, but by the quality (absolute) of the regulatory environment. Therefore, we advance the following hypothesis:

H1: The higher the quality of the regulatory environment of the host country, the less likely the firm will be to choose a joint venture, preferring to establish a wholly-owned subsidiary.

As to normative and cognitive distance, differences indeed matter, since they generate uncertainty. Therefore, we advance the following hypotheses:

H2: The greater the normative distance between the country of origin and the host country, the more likely the firm will be to choose a joint venture, rather than a wholly-owned subsidiary.

H3: The greater the cognitive distance between the country of origin and the host country, the more likely the firm will be to choose a joint venture, rather than a wholly-owned subsidiary.

\section{Firm characteristics}

International Experience - The IB literature consistently considers past experience as relevant for internationalization decisions. The importance of experience in firm internationalization is supported by behavioral theorists. A firm that already accumulated knowledge about foreign markets would need less support from local partners, and, therefore, would be less stimulated to create a joint venture (Johanson \& Vahlne, 1977). Several studies found that firms are more likely to establish wholly-owned subsidiaries when they have previous international experience (e.g. Agarwal \& Ramaswami, 1992; Anderson \& Gatignon, 1986); or that the greater the international experience, the greater the level of participation of the foreign firm in the capital of the subsidiary (Delios \& Beamish, 1999). On the other hand, less experienced companies tend to opt for joint ventures in order to share risks, to create learning mechanisms with local firms, and to facilitate access to host governments. Other studies show that the impact of the firm's experience is not limited only to the experience gained in the specific country, but includes experiences in other countries and industries (Delios \& Henisz, 2003). Nevertheless, some studies did not get support for the impact of international experience on the choice of ownership mode (e.g. Arslan \& Larimo, 2010; Kogut \& Singh, 1988). And Li and Meyer (2009) found that the effect of the firm's experience in the selection of entry mode varies according to the context of the host country. We hypothesize that,

H4: The greater the international experience of the firm with foreign direct investments, the less likely the firm will be to choose a joint venture, preferring to establish a wholly-owned subsidiary.

State Support - Several emerging countries show a high level of government interference on investment flows. For example, Chinese FDI is still predominantly made by state-owned enterprises (Buckley et al., 2007). As a result, the investment decisions of Chinese multinationals may reflect not only economic, but also political objectives. In Russia, state-owned enterprises account for about a quarter of the country's direct investment abroad (Sauvant, McAllister, \& Maschek, 2010). According to UNCTAD (2011), there were more than 650 multinational companies in the world with significant government participation in 2010. State-owned multinationals tend to be less reluctant than other firms to invest in environments with high institutional uncertainty (Knutsen, Rygh, \& Hveem, 2011). In such situations, the state-owned firm would expect adequate compensation by the local government in the event of expropriation or other measures that affect the firm's results negatively. A state-owned 
enterprise tends to be seen not only as a business organization, but also as a political actor. Thus, the firm may be subject to stricter criteria and controls, encouraging the formation of joint ventures with local partners, in order to legitimize its local operations (Cui \& Jiang, 2012). Thus,

H5: The larger the support of the government (of the firm's country of origin), the more likely the firm will be to choose a joint venture, rather than a wholly-owned subsidiary.

Size - Firm size, a proxy for its financial resources, can be considered one of the most important ownership advantages of the firm (Dunning, 1980). Thus, in studies on entry modes, firm size has been frequently used, either as an independent variable, or as a control variable (e.g. Agarwal, 1994; Barkema \& Vermeulen, 1998; Hennart \& Larimo, 1998; Kogut \& Singh, 1988; Xu, Pan, \& Beamish, 2004). In general, it is assumed that large corporations, with more resources, are more willing to choose entry strategies requiring greater volume of capital, while smaller firms prefer entry modes compatible with less capital (Agarwal \& Ramaswami, 1992; Brouthers \& Nakos, 2004). When establishing a wholly-owned subsidiary in a foreign country, a large firm could achieve economies of scale and scope, reducing its marginal cost (Meyer, 2001). Smaller firms, lacking resources, would give preference to shared-control entry modes (Contractor \& Kundu, 1998; Erramilli \& Rao, 1993). Thus,

H6: The larger the size of the firm, the less likely the firm will be to choose a joint venture, preferring to establish a wholly-owned subsidiary.

Economic Sector - The most common criterion used in the literature to differentiate industry is the dichotomy between industrial firms and service providers, since there are important distinctions between them that impact entry strategies in foreign markets (Demirbag, McGuinness, \& Altay, 2010; Dikova \& Witteloostuijn, 2007; Kogut \& Singh, 1988). Several factors can cause industrial companies and service providers to make different choices in their entry mode. For example, industrial firms are more subject to the uncertainties of the physical environment, while firms in the service sector are more susceptible to behavioral (cultural) issues. Therefore, firms engaging in manufacturing prefer joint ventures in environments with high levels of uncertainty, but when faced with behavioral problems they tend to choose wholly-owned subsidiaries. In contrast, in the face of uncertainties arising from behavioral issues, service firms would opt for joint ventures, whereas in environments with high levels of uncertainty, they tend to choose wholly-owned subsidiaries (Brouthers \& Brouthers, 2003). Thus,

H7: Firms in the service sector are more likely to choose a joint venture than a wholly-owned subsidiary.

Therefore, the conceptual model of the study proposes that the ownership mode adopted by a multinational firm in a host country is influenced by the host-country institutional environment and firm characteristics (Figure 1). The dependent variable, ownership mode, was measured using a dichotomic variable (wholly-owned subsidiary versus joint venture). 




Figure 1. Conceptual Model of the Study

\section{Operationalization}

Table 1 presents the operational variables used for the constructs Regulatory Quality, Normative Distance, and Cognitive Distance.

Table 1

\section{Variables of the Institutional Environment Used in the Study}

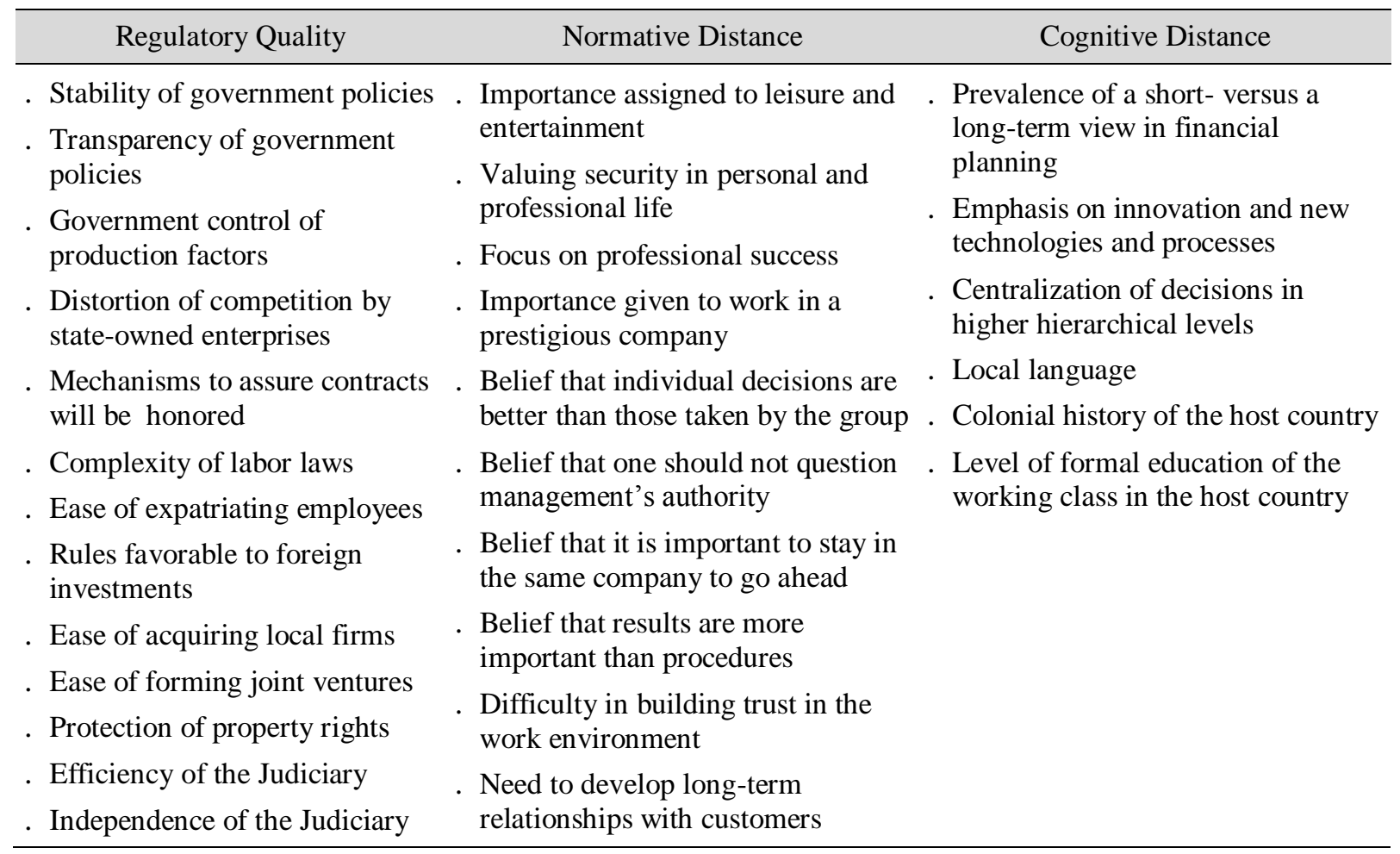

The firm's international experience was measured by the number of countries in which the firm had operations before establishing the specific subsidiary ( $c f$. Barkema \& Vermeulen, 1998; Dikova \& Witteloostuijn, 2007; Dow \& Larimo, 2011; Kogut \& Singh, 1988). State support was operationalized as a dummy variable; a company received state support if it was state-owned, the government was a minority shareholder, or the firm had long-term subsidized government financing. Size was measured 
by company gross sales, similarly to Demirbag, McGuinness and Altay's (2010) study. We used the four categories of size defined by The National Bank for Economic and Social Development (BNDES) based on the firm's gross operational revenue in 2012: small (less than $\mathrm{R} \$ 16$ million); medium (between R \$16 and 90 million); medium-large (between $\mathrm{R} \$ 90$ and 300 million); and large (more than $\mathrm{R} \$ 300$ million). Economic sector was operationalized as a dummy variable (manufacturing or services).

\section{Methodology}

The study is cross-sectional and ex post facto. The research method adopted was a survey of Brazilian multinationals, and the unit of analysis was the foreign subsidiary of a Brazilian multinational. There is no official and exhaustive list of Brazilian companies with foreign operations and their subsidiaries. The list used in the study was obtained from BNDES. The list includes all types of multinationals independent of size and of connections with the bank, and is considered the most complete and reliable list of Brazilian multinationals available in the country.

Only subsidiaries with value-added activities were considered part of the target population; subsidiaries in tax-haven countries were excluded. A total of 198 companies fulfilled the selection criteria, with 587 subsidiaries spread across 84 countries. A maximum number of four subsidiaries by company was set in order to avoid excessive weight of a small number of large companies with many subsidiaries. Thus, the target population was reduced to 432 subsidiaries of 198 companies. The respondent was, preferably, a Brazilian executive, CEO of the foreign subsidiary, who had participated in the decision to establish the subsidiary, or as close as possible to this profile.

The sample was non probabilistic, due to the lack of a comprehensive list of the population, the occurrence of non-response, and the fact that companies with more than four subsidiaries self-selected which of their subsidiaries were to be included in the sample. We proposed the following criteria for selecting the subsidiaries: (a) the subsidiaries should have strategic relevance for the company; (b) the choice of the host country should have been based on previous studies before the decision was taken. A total of 192 questionnaires were received from 106 companies, representing a response rate of $44 \%$ of the subsidiaries concerned and 54\% of the multinationals in the research population. Nevertheless, the final sample used consisted of 165 questionnaires, or $40 \%$ of the target population of subsidiaries, due to questionnaires with inconsistencies or that were completed with data from subsidiaries whose functions were not included in the study. To identify a potential non-response bias, non-parametric tests were conducted to verify whether non-respondents differed significantly from respondents in terms of the geographic location of their headquarters in Brazil and level of economic development of the subsidiary's host country; differences between the two groups were non-significant for both variables, suggesting the absence of non-response bias. The data collection instrument was a selfadministered questionnaire with closed-ended questions and 5-point Likert-type scales. Questionnaires were submitted to the scrutiny of five specialists (university professors in the area of International Business and executives from BNDES) and pre-tested with five executives from Brazilian MNEs. The questionnaire was posted on the internet, as well as sent by e-mail to the respondents that indicated a preference for this means of data collection. Returned questionnaires were examined to detect potential errors, and several respondents were contacted to clarify issues as well as to fill in missing data. Finally, an analysis of outliers and missing data was conducted. 


\section{Results}

\section{Exploratory factor analysis results}

Exploratory factor analysis was used to investigate the perceived dimensions of the host country institutional environment and therefore reduce the data to a manageable number of factors (Table 2). Data was examined to ascertain that it filled the requirements of factor analysis; correlation matrices showed a reasonable number of significant correlations, the results of the Bartlett's tests were significant and the values of MSA in the KMO tests were considered adequate. The analysis used principal component analysis and orthogonal varimax rotation; the factors extracted had eigenvalues greater than 1. Reliability was checked using Cronbach's alpha; all coefficients were greater than 0.60.

Table 2

\section{Exploratory Factor Analysis Results}

\begin{tabular}{llc}
\hline Factor & Variable & Quality of the Regulatory Environment \\
\hline 1 & \multicolumn{1}{c}{ Stability of government policies } & .686 \\
$\begin{array}{l}\text { Quality of } \\
\text { Government } \\
\text { Institutions }\end{array}$ & Transparency of government policies & .707 \\
& Adequacy of the protection of property rights & .791 \\
& Simplicity of the instruments of protection of property rights & .821 \\
& Efficiency of the Judiciary & .843 \\
\hline $\begin{array}{l}\text { Prevalence of } \\
\text { Market-Based } \\
\text { Arrangements }\end{array}$ & Independence of the Judiciary & .838 \\
\hline
\end{tabular}

\begin{tabular}{llc}
\hline \multicolumn{1}{l}{ Total variance explained: $68.0 \%$} & \multicolumn{1}{c}{ Normative Distance } \\
\hline & & .758 \\
\hline Values & Importance assigned to leisure and entertainment & .753 \\
& Valuing security in personal and professional life & .690 \\
\hline 2 & Focus on professional success & .625 \\
Beliefs & Importance given to work in a prestigious company & .727 \\
& Belief that one should not question management's authority & .760 \\
\hline 3 & Belief that it is important to stay in the same company to go ahead & .716 \\
Relationships & Difficulty in building trust in the work environment & .746 \\
\hline
\end{tabular}

Total variance explained: $59.2 \%$ 
Table 2 (continued)

\begin{tabular}{llc}
\hline Factor & Variable & Loading \\
\hline & & \multicolumn{1}{c}{ Cognitive Distance } \\
\hline 1 & Local language & .729 \\
Cultural & Colonial history & .878 \\
Identity & Level of formal education of the working class & .767 \\
& Prevalence of a short- versus a long-term view in financial planning & .754 \\
Management & Emphasis on innovation and new technologies and processes & .753 \\
Practices & Centralization of decisions in higher hierarchical levels & .808 \\
\hline
\end{tabular}

Total variance explained: $62.4 \%$

The two factors of the construct Quality of the Regulatory Environment - Quality of Government Institutions and Prevalence of Market-based Arrangements - together explained 68\% of the variance. The first factor, Quality of Government Institutions, included six variables commonly used in international business literature to measure government effectiveness and rule of law. The second factor, Prevalence of Market-based Arrangements, combines three variables related to government controls that affect doing business. The three factors of the construct Normative Distance together explained $59.2 \%$ of the variance. The first factor, Values, includes three variables: importance assigned to leisure and entertainment, valuing security, and focus on professional success. The second factor, Beliefs, includes the conviction that one should not question management's authority, that it is important to stay in the same company to go ahead, and that it is important to work in a prestigious company. Finally, the two factors of the construct Cognitive Distance together explained $62.4 \%$ of the variance. The first factor, Cultural Identity, includes three variables (language, colonial history, and level of education). The second factor, Management Practices, includes three variables: the prevalence of a short- versus a long-term view, emphasis on innovation, and administrative centralization.

Summated scales (Spector, 1992) were used to form the independent variables to be used in logistic regression. No relevant multicollinearity was found, with low VIF (Variance Inflation Factor) values.

\section{Hypotheses testing}

Three models were tested using binary logistic regression: Model 1, only with firm characteristics; Model 2, only with factors of the host country institutional environment; and Model 3, with all factors. Casewise diagnostics led to the exclusion of nine cases, further reducing the sample to 157 cases. Table 3 presents the model summary using the enter method.

Table 3

\section{Model Summary (Enter Method)}

\begin{tabular}{|c|c|c|c|c|c|c|c|}
\hline \multirow[t]{2}{*}{ Model } & \multirow[t]{2}{*}{$-2 \mathrm{LL}$} & \multirow[t]{2}{*}{ Cox \& Snell $\mathrm{R}^{2}$} & \multirow[t]{2}{*}{ Nagelkerke $\mathrm{R}^{2}$} & \multicolumn{3}{|c|}{ Hosmer \& Lemeshow } & \multirow[t]{2}{*}{$\%$ correct } \\
\hline & & & & Chi-square & df & sig & \\
\hline 1 & 126.559 & .140 & .227 & 2.978 & 8 & .936 & 73.2 \\
\hline 2 & 128.713 & .128 & .208 & 5.349 & 7 & .617 & 68.8 \\
\hline 3 & 93.031 & .305 & .496 & 6.892 & 8 & .548 & 79.0 \\
\hline
\end{tabular}

Note. $\mathrm{N}=157$; Cutvalue $=0.185$. 
All the tests for Model 3 showed the best results. The chi-square was significant and the Hosmer $\&$ Lemeshow test was non-significant, suggesting good fit of the data. The hit ratio was $79 \%$. Because of the different size of the two groups, the cutvalue was 0.185 . The percentage of cases correctly classified was $78.9 \%$ for wholly-owned subsidiaries and $79.3 \%$ for joint ventures (Table 4 ).

Table 4

Classification Matrix

\begin{tabular}{llccc}
\hline \multicolumn{2}{c}{ Observed } & \multicolumn{3}{c}{ Predicted } \\
\cline { 3 - 5 } & & Wholly-owned & Joint venture & $\%$ correct \\
\hline Ownership Mode & Wholly-owned & 101 & 27 & 78.9 \\
& Joint venture & 6 & 23 & 79.3 \\
\hline Overall Percentage & & & 79.0 \\
\hline
\end{tabular}

Note. $\mathrm{N}=157$; Cutvalue $=0.185$.

Table 5 presents the results of the tests of hypotheses.

Table 5

Variables in the Equation (Model 4)

\begin{tabular}{llccc}
\hline Hypothesis & Factors & B & Exp(B) & Sig \\
\hline H1 - Regulatory & Quality of government institutions & -1.040 & 0.354 & .002 \\
& Prevalence of market-based arrangements & -0.431 & 0.650 & .178 \\
\hline H2 - Normative & Values & 0.120 & 1.127 & .729 \\
distance & Beliefs & -0.991 & 0.371 & .032 \\
& Relationships & 0.153 & 1.165 & .676 \\
\hline H3 - Cognitive & Cultural Identity & 0.761 & 2.141 & .044 \\
distance & Management Practices & 1.337 & 3.807 & .003 \\
\hline H4 - Firm international experience (no. of years) & 0.026 & 1.026 & .407 \\
H5 - State support (yes/no) & 2.525 & 12.488 & .000 \\
H6 - Size (sales) & & 0.379 & 1.461 & .378 \\
H7 - Economic sector (manufacturing/services) & 2.667 & 14.396 & .000 \\
\hline
\end{tabular}

Hypotheses $\mathrm{H} 1$ and $\mathrm{H} 2$ received only partial empirical support. In the case of Hypothesis 1, concerning the Regulatory Quality, the factor that showed significant results was Quality of Government Institutions, suggesting that in countries whose regulatory environment shows a high quality of public administration companies are more likely to choose wholly-owned subsidiaries. With respect to Hypothesis 2 (Normative Distance), the factor that showed a statistically significant result was Beliefs. Note, however, that the results indicate that larger differences in beliefs would increase the probability of creating wholly-owned subsidiaries, contradicting our original hypothesis, but supporting the results previously reported by Arslan and Larimo (2010). One possible explanation for this result is that very different beliefs can make it difficult to identify a suitable partner. Values and Relationships did not show significant results.

Regarding Hypothesis 3 (Cognitive Distance), both factors were significant. The results for the factor Management Practices indicate that the greater the perceived differences between the 
management practices of the host country and those of Brazil, the more likely it is that the firm uses a joint venture. These results are particularly relevant when considering the small number of joint ventures in the sample, given the preference of Brazilian multinationals for wholly-owned subsidiaries. Thus, they also offer empirical support to the dominant hypothesis in the literature on ownership mode for EMNEs. Strong differences in business practices make an association with local partners interesting in order to take advantage of their local market knowledge, instead of the firm itself seeking to acquire this knowledge (which would require more time and money, and could increase risks). The Cultural Identity factor was also significant, giving support to the importance of indicators of cultural distance and psychic distance used in the literature on ownership modes.

Hypothesis 4 and 6 were not supported empirically. Hypotheses 5 and 7 showed empirical support in the hypothesized direction. The Exp (B) of the variable State Support was 12.488 ( $<<0.001$ ), showing a strong and significant relationship between state support and choice of joint ventures. With respect to Hypothesis $7(\operatorname{Exp}(B)=14.396, p<0.001)$, the results indicate that Brazilian multinationals in the service sector strongly favor joint ventures.

\section{Discussion}

In general, Brazilian multinationals show a strong preference for wholly-owned subsidiaries ( $75 \%$ of the sample), compared to joint ventures $(25 \%)$. These findings suggest relevant differences in relation to multinationals from other countries, and confirm the results obtained by Dias (2012). Rocha (2003) and Silva, Rocha and Carneiro (2009) contend that Brazilian firms prefer to take full control of their businesses, a cultural preference that also appears in the high percentage of preferred shares (without voting rights, but with preference in receiving dividends) of Brazilian companies that go public. These authors suggest that such behavior would be more common when firms internationalize their businesses to neighboring countries. Considering that most Brazilian multinationals are still regional (53\% of the subsidiaries in the sample are in Latin America and 21\% in North America), their proposition could help explain these findings. However, a question open for discussion is whether such behavior can also be found in the initial steps of internationalization of traditional multinationals. Unfortunately that are no studies based on large samples that can help understand whether these preferences were also present in their initial choices.

Two of the three hypotheses concerning the institutional environment of the host country have received only partial empirical support, suggesting that some institutional factors studied were not statistically significant in explaining the ownership mode of Brazilian multinationals. There are several possible explanations for these results.

In the case of the construct Regulatory Quality, two factors were identified but only one (Quality of Government Institutions) was significantly associated with the selection of wholly-owned subsidiaries, as generally predicted in the literature (e.g. Morschett, Schramm-Klein, \& Swoboda, 2010; Slangen \& Tulder, 2009; Xu et al., 2004). This result also supports our contention that, in the case of EMNEs, researchers should not consider the regulative distance, but rather the absolute quality of the regulatory environment of the host country. Brazilian multinationals do take into account the stability and transparency of government policies, the protection of property rights, and the efficiency and independence of the judiciary system, and such aspects influence their decision of ownership mode, in the same way they influence their counterparts from other countries. The fact that the factor Prevalence of Market-Based Arrangements (which includes aspects related to the complexity of labor laws, government control of production factors and the presence of state enterprises distorting competition) did not show significant results does not imply, however, that Brazilian multinationals prefer institutional environments with low quality regarding these aspects. The non-significant results can be explained by the Brazilian institutional environment in which these aspects are also present. Being used to dealing with them, decision makers at Brazilian multinationals do not consider such factors important when deciding ownership mode. 
We contend, therefore, that because EMNEs originate from countries with poor institutional environments, researchers should be careful when evaluating the influence of regulative distance in their internationalization decision processes. In this study, although decision makers did perceive institutional weaknesses and risks in the countries where they chose to establish their subsidiaries, part of these aspects do not seem to impact the ownership mode decision, probably because they are used to operating in an environment with similar characteristics. Again, they do not show preference, but rather less concern, for this type of environment when choosing the ownership mode. Thus, our proposal of using the absolute quality of the regulatory environment in the case of EMNEs, rather than the regulative distance, is consistent with this study's result.

As to the construct normative distance, the factor Values was also non-significant, which is consistent with the fact that the two main host countries of Brazilian FDI are Argentina (25\%) and the United States (19\%), which belong to different cultural clusters. The factor Beliefs, however, was significant, although in a direction contrary to hypothesized. In our study, the larger the perceived differences in beliefs, the more the firm would tend to choose a wholly-owned subsidiary. An explanation for why beliefs would significantly impact the ownership-mode decision, and values would not, may rest in the nature of these constructs. Beliefs are not as deeply rooted and stable in time as values; they relate more to "practices", which belong to more superficial "layers of culture" ( $c f$. Hofstede, 1991, pp. 9-10). Therefore, differences in beliefs may actually impact foreign operations more than differences in values. The fact that the direction of the relationship was contrary to hypothesized is not totally surprising; in fact the literature shows ambivalent results in the relationship between ownership mode and cultural distance, a construct similar to normative distance, also including values and beliefs. Of the 13 studies on the relationship between ownership mode and cultural distance reviewed by Harzing (2004), six found a negative relationship, four a positive relationship, and the other three did not show significant results.

As to Cognitive Distance, the factors Cultural Identity and Management Practices were significantly related to ownership-mode decision as hypothesized. Cultural Identity refers to some of the most basic differences between the domestic and the host country, those related to language, cultural roots, and education. In addition, management practices are extremely relevant to foreign operations; large differences in management practices increase the need to adapt the firm's internal routines, and make communication between subsidiaries and the parent company more difficult. When management practices differ substantially between managers in a joint venture, the risk of conflict is increased.

Firm characteristics showed interesting results; state support and belonging to the service sector positively and significantly impacted the choice of joint ventures, while size and international experience did not significantly relate to ownership mode. Some authors suggest that the type of experience (general or host country specific) and the context in which experience is accumulated (institutionally-similar countries or not) can generate different results (Dow \& Larimo, 2011; Henisz \& Delios, 2002; Li \& Meyer, 2009). Therefore, the very way to operationalize the construct International Experience may produce different results.

The strong role played by state support in the choice of joint ventures is also an important finding. State support tends to be available more often to larger firms or firms that advanced further in their internationalization process. Firms with a global scope of operations tend to be operating in countries with greater institutional distance, or in countries with greater institutional constraints to the installation of wholly-owned subsidiaries, thus potentially preferring or being forced to use joint ventures. Therefore, these firms are more prone to get state support than smaller firms with a limited scope of internationalization. In addition, state support might have encouraged Brazilian multinationals to engage in joint ventures that they would not enter without such support, such as countries with high political risk, fragile institutions, or large cultural distance (e.g. Holburn \& Zelner, 2010; Quer, Claver, \& Rienda, 2012). In these situations, having the state as a shareholder or a major source of financing might act as a protection against those risks for the EMNE (Knutsen et al., 2011). 
Finally, in spite of the small number of Brazilian multinationals in the service sector, a reasonable number of them are in high-tech industries, which could explain the preference for joint ventures of service firms as a way to attain legitimacy in foreign markets, since Brazil has no reputation for producing technology. Moreover, due to the intangibility of services and the need for tacit knowledge to serve new markets, service multinationals may be seeking access to market knowledge and know-how held by local partners. These results are consistent with theoretical propositions and empirical findings in the literature (e.g. Brouthers \& Brouthers, 2003; Morschett et al., 2010).

\section{Conclusions}

This study aimed to contribute to the understanding of the choice of ownership mode by EMNEs. Its theoretical contribution relies in examining the phenomenon under the perspective of institutionalism in an emerging country, Brazil. The institutional quality of a country's environment is a complex and still poorly explored research area, particularly regarding the use of perceptual measures, since most studies have employed existing indicators from secondary sources. The selection of variables to measure each institutional pillar, after a broad review of the extant literature on entry modes, may contribute to future studies, particularly to those focused on other emerging countries.

The findings suggest that Brazilian MNE choice of ownership mode agrees in general with the theoretical arguments and previous studies in the extant literature. There are, however, specific aspects that can be of interest to researchers that look specifically at EMNEs. First, the assumption that regulative distance, and not the regulatory environment in absolute terms, affects the choice of ownership mode seems not to stand for EMNEs that come from less stable institutional environments. Second, state support showed a strong relationship with the choice of ownership mode in this study. State support has not been previously researched since traditional MNEs from developed countries do not show this characteristic, which is more typical of EMNEs. Therefore, we suggest that future studies on EMNEs should take this variable into consideration.

The disposition of Brazilian multinationals to establish subsidiaries in countries with fragile institutional environments suggests that their experience in the home country makes it easier for them to operate in similar environments. These findings also support the view that emerging multinationals are less sensitive to institutional weaknesses in the host countries (Gammeltoft, Filatotchev, \& Hobdari, 2012).

The limitations of this research are related to its scope, the methodology used and the data available. The use of perceptual measures collected directly from respondents has its advantages and disadvantages. On the positive side, the relevant variables to measure are the decision makers' perceptions of the institutional environment, and not objective measures of the institutional quality of the environment, since the former, not the latter, guide firms' investment decisions. Moreover, the perceptions of decision makers from EMNEs may be substantially different from those of executives from developed countries. On the negative side, this type of research suffers of an ex post facto bias. Finally, sample size did not permit the use of a holdout sample; therefore our results may suffer from an upward bias in terms of the percentage of cases correctly classified.

\section{References}

Agarwal, S. (1994). Socio-cultural distance and the choice of joint ventures: a contingency perspective. Journal of International Marketing, 2(2), 63-80. 
Agarwal, S., \& Ramaswami, S. N. (1992). Choice of foreign market entry mode: impact of ownership, location and internalization factors. Journal of International Business Studies, 23(1), 1-28. doi: 10.1057/palgrave.jibs.8490257

Anderson, E., \& Gatignon, H. (1986). Modes of foreign entry: a transaction cost analysis and propositions. Journal of International Business Studies, 17(2), 1-26. doi: 10.1057/palgrave.jibs. 8490432

Arslan, A., \& Larimo, J. (2010). Ownership strategy of multinational enterprises and the impacts of regulative and normative institutional distance: evidence from Finnish foreign direct investments in Central and Eastern Europe. Journal of East West Business, 16(3), 179-200. doi: $10.1080 / 10669868.2010 .523370$

Barkema, H. G., \& Vermeulen, F. (1998). International expansion through start-up or acquisition: a learning perspective. Academy of Management Journal, 41(1), 7-26.

Brouthers, K. D. (2013). A retrospective on: institutional, cultural and transaction cost influences on entry mode choice and performance. Journal of International Business Studies, 44(1), 14-22. doi: $10.1057 /$ jibs.2012.23

Brouthers, K. D., \& Brouthers, L. E. (2003). Why service and manufacturing entry mode choices differ: the influence of transaction cost factors, risk and trust. Journal of Management Studies, 40(5), 1179-1204. doi: 10.1111/1467-6486.00376

Brouthers, K. D., \& Nakos, G. (2004). SME Entry mode choice and performance: a transaction cost perspective. Entrepreneurship: Theory and Practice, 28(3), 229-247. doi: 10.1111/j.15406520.2004.00041.x

Buckley, P. J., Clegg, L. J., Cross, A. R., Liu, X., Voss, H., \& Zheng, P. (2007). The determinants of Chinese outward foreign direct investment. Journal of International Business Studies, 38(4), 499-518. doi: 10.1057/jibs.2008.102

Chan, C. M., Isobe, T., \& Makino, S. (2008). Which country matters? Institutional development and foreign affiliate performance. Strategic Management Journal, 29(11), 1179-1205. doi: $10.1002 / \mathrm{smj} .705$

Chen, H., \& Hu, M. Y. (2002). An analysis of entry mode and its impact on performance. International Business Review, 11(2), 193-210. doi: 10.1016/S0969-5931(01)00055-5

Contractor, F. J., \& Kundu, S. K. (1998). Modal choice in a world of alliances: analyzing organizational forms in the international hotel sector. Journal of International Business Studies, 29(2), 325-358. doi: 10.1057/palgrave.jibs.8490039

Cuervo-Cazurra, A. (2012). Extending theory by analyzing developing country multinational companies: solving the goldilocks debate. Global Strategy Journal, 2(3), 153-167. doi: 10.1111/j.2042-5805.2012.01039.x

Cui, L., \& Jiang, F. (2012). State ownership effect on firms' FDI ownership decisions under institutional pressure: a study of Chinese outward-investing firms. Journal of International Business Studies, 43(4), 264-284. doi: 10.1057/jibs.2012.1

Delios, A., \& Beamish, P. W. (1999). Ownership strategy of Japanese firms: transactional, institutional and experience influences. Strategic Management Journal, 20(10), 915-933. doi: 10.1002/(SICI)1097-0266(199910)20:10<915::AID-SMJ51>3.0.CO;2-0

Delios, A., \& Henisz, W. J. (2003). Political hazards, experience, and sequential entry strategies: the international expansion of Japanese firms, 1980-1998. Strategic Management Journal, 24(11), 1153-1164. doi: 10.1002/smj.355 
Demirbag, M., McGuinness, M., \& Altay, H. (2010). Perceptions of institutional environment and entry mode: FDI from an emerging country. Management International Review, 50(2), 207-240. doi: $10.1007 / \mathrm{s} 11575-010-0028-1$

Dias, A. C. A. M. (2012). A escolha do modo de entrada no mercado externo e sua relação com o desempenho da subsidiária: evidências das empresas multinacionais brasileiras (Tese de doutorado). Departamento de Administração, Pontifícia Universidade Católica do Rio de Janeiro, Rio de Janeiro, RJ, Brasil. Recuperado de http://www2.dbd.pucrio.br/pergamum/biblioteca/php/mostrateses.php?open=1\&arqtese=0612035_2012_Indice.html

Dikova, D., \& Witteloostujin, A. van (2007). Foreign direct investment mode choice: entry and establishment modes in transition economies. Journal of International Business Studies, 38(6), 1013-1033. doi: 10.1057/palgrave.jibs. 8400297

Dow, D., \& Larimo, J. (2011). Disentangling the roles of international experience and distance in establishment mode choice. Management International Review, 51(3), 321-355. doi: 10.1007/s11575-011-0080-5

Dunning, J. H. (1980). Toward an eclectic theory of international production: some empirical tests. Journal of International Business Studies, 11(1), 9-31.

Dunning, J. H., \& Lundan, S. M. (2008). Institutions and the OLI paradigm of the multinational enterprise. Asia Pacific Journal of Management, 25(4), 573-593. doi: 10.1007/s10490-0079074-z

Eden, L., \& Miller, S. R. (2004). Distance matters: liability of foreignness, institutional distance and ownership strategy. In M. Hitt \& J. Cheng (Eds.), Theories of the multinational enterprise: diversity, complexity and relevance (Vol. 16, pp. 187-221). New York, NY: Emerald.

Erramilli, M. K., \& Rao, C. P. (1993). Service firms' entry-mode choice: a modified transaction cost analysis approach. Journal of Marketing, 57(3), 19-38.

Estrin, S., Baghdasaryan, D., \& Meyer, K. E. (2009). The impact of institutional and human resource distance on international entry strategies. Journal of Management Studies, 46(7), 1171-1196. doi: 10.1111/j.1467-6486.2009.00838.x

Gammeltoft, P., Filatotchev, I., \& Hobdari, B. (2012). Emerging multinational companies and strategic fit: a contingency framework and future research agenda. European Management Journal, 30(3), 175-188. doi: 10.1016/j.emj.2012.03.007

Goodnow, J. D., \& Hansz, J. E. (1972) Environmental determinants of overseas market entry strategies. Journal of International Business Studies, 3(1), 33-50. doi: 10.1057/palgrave.jibs. 8490740

Grosse, R., \& Trevino, L. J. (2005). New institutional economics and FDI location in Central and Eastern Europe. Management International Review, 45(2), 123-145.

Harzing, A.-W. (2004). The role of culture in entry-mode studies: from neglect to myopia? In J. L. C. Cheng \& M. A. Hitt (Eds.), Managing multinationals in a knowledge economy: economics, culture and human resources (Vol. 15, pp. 75-127). Bingley, UK: Emerald Group Publishing Limited.

Henisz, W. J., \& Delios, A. (2002). What determines success and failure in international competition? Learning about the institutional environment. In P. Ingram \& B. S. Silverman (Eds.), The new institutionalism in strategic management (Vol. 19, pp. 339-372). Oxford: Elsevier.

Hennart, J.-F. (1982). A theory of multinational enterprise. Ann Arbor: University of Michigan Press. 
Hennart, J.-F. (2012). Emerging market multinationals and the theory of the multinational enterprise. Global Strategy Journal, 2(3), 168-187. doi: 10.1111/j.2042-5805.2012.01038.x

Hennart, J.-F., \& Larimo, J. (1998). The impact of culture on the strategy of multinational enterprises: does national origin affect ownership decisions? Journal of International Business Studies, 29(3), 515-538. doi: 10.1057/palgrave.jibs.8490005

Hofstede, G. (1980). Culture's consequences: international differences in work-related values. Beverly Hills, CA: Sage Publications.

Hofstede, G. (1991). Cultures and organizations: software of the mind. London: McGraw-Hill.

Holburn, G. L. F., \& Zelner, B. A. (2010). Political capabilities, policy risk, and international investment strategy: evidence from the global electric power generation industry. Strategic Management Journal, 31(2), 1290-1315. doi: 10.1002/smj.860

Johanson, J., \& Vahlne, J.-E. (1977). The internationalization process of the firm: a model of knowledge development and increasing foreign market commitments. Journal of International Business Studies, 8(1), 23-32. doi: 10.1057/palgrave.jibs.8490676

Knutsen, C. H., Rygh, A., \& Hveem, H. (2011). Does state ownership matter? Institutions' effect on foreign direct investment revisited. Business and Politics, 13(1), 1-31. doi: 10.2202/14693569.1314

Kogut, B., \& Singh, H. (1988). The effect of national culture on the choice of entry mode. Journal of International Business Studies, 19(3), 411-432. doi: 10.1057/palgrave.jibs.8490394

Kostova, T. (1999). Transnational transfer of strategic organizational practices: a contextual perspective. The Academy of Management Review, 24(2), 308-324. doi: 10.5465/AMR.1999.1893938

Kostova, T., \& Roth, K. (2002). Adoption of an organizational practice by the subsidiaries of the MNC: institutional and relational effects. Academy of Management Journal, 45(1), 215-233. doi: $10.2307 / 3069293$

Kostova, T., \& Zaheer, S. (1999). Organizational legitimacy under conditions of complexity: the case of the multinational corporation. Academy of Management Review, 24(1), 64-81. doi: 10.5465/AMR.1999.1580441

Li, P.-Y., \& Meyer, K. E. (2009). Contextualizing experience effects in international business: a study of ownership strategies. Journal of World Business, 44(4), 370-382. doi: 10.1016/j.jwb.2008.11.007

López-Duarte, C., \& Vidal-Suaréz, M. M. (2013). Cultural distance and the choice between wholly owned subsidiaries and joint ventures. Journal of Business Research, 66(11), 2252-2261. doi: 10.1016/j.jbusres.2012.02.017

Meyer, K. E. (2001). Institutions, transaction costs, and entry mode choice in Eastern Europe. Journal of International Business Studies, 32(2), 357-367. doi: 10.1057/palgrave.jibs.8490957

Morschett, D., Schramm-Klein, H., \& Swoboda, B. (2010). Decades of research on market entry modes: what do we really know about external antecedents of entry mode choice? Journal of International Management, 16(1), 60-77. doi: 10.1016/j.intman.2009.09.002

Peng, M. W. (2009). Global business. Cincinnati, OH: South-Western Cengage Learning. 
Phillips, N., Tracey, P., \& Karra, N. (2009). Rethinking institutional distance: strengthening the tie between new institutional theory and international management. Strategic Organization, 7(3), 339-348. doi: 10.1177/1476127009337439

Quer, D., Claver, E., \& Rienda, L. (2012). Political risk, cultural distance, and outward foreign direct investment: empirical evidence from large Chinese firms. Asia Pacific Journal of Management, 29(4), 1089-1104. doi: 10.1007/s10490-011-9247-7

Ramamurti, R. (2012). What is really different about emerging market multinationals? Global Strategy Journal, 2(1) 41-47. doi: 10.1002/gsj.1025

Rocha, A. (2003). Por que as empresas brasileiras não se internacionalizam? In A. Rocha (Ed.), As novas fronteiras: a multinacionalização das empresas brasileiras (pp. 13-28). Rio de Janeiro: Mauad.

Rugman, A. M. (1981). Inside the multinationals: the economics and internal markets. New York: Columbia University Press.

Sauvant, K. P. (2008). The rise of TNCs from emerging markets: the issues. In K. P. Sauvant (Ed.), The rise of transnational corporations from emerging markets: threat or opportunity? (pp. 158180). Cheltenham, UK: Edward Elgar Publishing.

Sauvant, K. P., McAllister, G., \& Maschek, W. A. (2010). Foreign direct investments from emerging markets: the challenges ahead. New York: Palgrave Macmillan.

Scott, W. R. (2001). Institutions and organizations: ideas and interests (2nd ed.). Thousand Oaks: Sage.

Shenkar, O. (2001). Cultural distance revisited: towards a more rigorous conceptualization and measurement of cultural differences. Journal of International Business Studies; 32(3), 519-535. doi: $10.1057 /$ palgrave.jibs. 8490982

Silva, J. F., Rocha, A., \& Carneiro, J. (2009). The international expansion of firms from emerging markets: toward a typology of Brazilian MNEs. Latin American Business Review, 10(2/3), 95115. doi: 10.1080/10978520903303638

Slangen, A. H. L., \& Tulder, R. van (2009). Cultural distance, political risk, or governance quality? Towards a more accurate conceptualization and measurement of external uncertainty in foreign entry mode research. International Business Review, 18(3), 276-291. doi: 10.1016/j.ibusrev.2009.02.014

Spector, P. E. (1992). Summated rating scale construction: an introduction (Quantitative applications in the social sciences). Thousand Oaks: Sage Publications.

Trevino, L. J., Thomas, D. E., \& Cullen, J. (2008). The three pillars of institutional theory and FDI in Latin America: an institutionalization process. International Business Review, 17(1), 118-133. doi: 10.1016/j.ibusrev.2007.10.002

Tung, R. L., \& Verbeke, A. (2010). Beyond Hofstede and GLOBE: improving the quality of crosscultural research. Journal of International Business Studies, 41(8), 1259-1274. doi: $10.1057 /$ jibs.2010.41

United Nations Conference on Trade and Development. (2011). World investment report 2011: Nonequity modes of international production and development. Retrieved from http://unctad.org/en/docs/wir2011_embargoed_en.pdf 
United Nations Conference on Trade and Development. (2014). World investment report 2014: Investing in the SDGs: an action plan. Retrieved from http://unctad.org/en/PublicationsLibrary/wir2014_en.pdf

Xu, D., Pan, Y., \& Beamish, P. W. (2004). The effect of regulative and normative distances on MNE ownership and expatriate strategies. Management International Review, 44(3), 285-307.

\section{Authors' Profiles}

Henrique de Azevedo Ávila

Av. República do Chile, 100, 20031-917, Rio de Janeiro, RJ, Brazil. E-mail address: henavila@uol.com.br

Angela da Rocha

Rua Marquês de São Vicente, 225, Gávea, 22451-900, Rio de Janeiro, RJ, Brazil. E-mail address: amc.darocha@ gmail.com

Jorge Ferreira da Silva

Rua Marquês de São Vicente, 225, Gávea, 22451-900, Rio de Janeiro, RJ, Brazil. E-mail address: shopshop@iag.puc-rio.br 